\begin{tabular}{|c|c|}
\hline 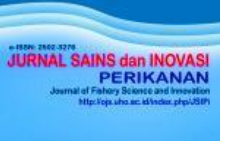 & $\begin{array}{c}\text { JURNAL SAINS dan INOVASI PERIKANAN } \\
\text { Journal of Fishery Science and Innovation } \\
\text { e-ISSN: } 2502-3276\end{array}$ \\
\hline ग & $\begin{array}{c}\text { Vol. 1, No.1, 31-39, Januari } 2017 \\
\text { http://ojs.uho.ac.id/index.php/JSIPi }\end{array}$ \\
\hline
\end{tabular}

\title{
Preferensi Habitat Kerang Coklat (Modiolus modulaides) pada Perairan Bagian Dalam dan Luar Teluk Kendari Sulawesi Tenggara
}

\section{Habitat Preference of Brown Mussel (Modiolus modulaides) In Kendari Bay Southeast Sulawesi}

\author{
La Ode Musni ${ }^{1)}$, Muhammad Ramli ${ }^{2 *}$, Bahtiar $^{2)}$ \\ ${ }^{1)}$ Mahasiswa Program Studi Magister Ilmu Perikanan Pascasarjana Univ. Halu Oleo, \\ ${ }^{1)}$ Staf Dinas Kelautan dan Perikanan Provinsi Sulawesi Tenggara, \\ ${ }^{2)}$ Fak Perikanan dan Ilmu Kelautan Universitas Haluo Oleo \\ Corresponding author ${ }^{*}$ : laodemusni@yahoo.com,muhammadramli186@yahoo.co.id, anan77unhalu@gmail.com
}

\begin{abstract}
Brown mussel (Modiolus modulaides), family Mytilidae, has a considerably high economic value. This species has been exploited for decades in Kendari Bay without proper management to sustain its population. Currently, there is no information available about habitat preferences of this species to support its management measures. Therefore, this study aim is to determine the distribution and density of brown mussel population in Kendari Bay related to its environment. Sampling was done daily in February to June 2015 using purposive sampling at seven sampling stations. Total brown mussels found was 1.453 individuals. The density and distribution data of the shells were analyzed descriptively using the standard formula. The result of the distribution analysis was then tested with chi square $\left(\chi^{2}\right)$. Habitat preference of brown mussel was analyzed using Principle Componen Analysis (PCA) and Corespondent Analysis (CA) in XLSTAT 2014. Brown mussel density ranged from 6.33 to 32.20 mussels. $\mathrm{m}^{-2}$. Size distribution analysis of shell length showed that mussels were divided into 12 class sizes and based on their size, they were considered as either juvenile (young), adult and mature/aged mussels in the size range of 0.2 to $4.65 \mathrm{~cm}$, 4.7 to $7.6 \mathrm{~cm}$ and 7.65 to $8.7 \mathrm{~cm}$, respectively. An increasing number of mussels was correlated to the level of roughness and type of the substrates and the presence of seagrass and mangrove. Furthermore, size categories of mussels were associated with the type of substrate, currents, and its interactions with other benthic organisms. This study found that habitat preferences of brown mussel were characterized by very coarse sand substrates, fine sands, and its interaction with the physical (clarity of water and current), chemical (dissolved oxygen) and biological (chlorophyll-a and Total Organic Matter (TOM) of water quality parameters as well as the presence of seagrass and mangrove ecosystems.
\end{abstract}

Keywords: Brown mussel, habitat preferences, density, size distribution

\section{ABSTRAK}

Kerang Modiolus modulaides termasuk family Mytilidae dan mempunyai nilai ekonomis. Berbagai aktivitas pengambilan serta pemanfaatannya sampai saat ini masih dilakukan dengan mengeksploitasi langsung tanpa kegiatan pengelolaannya. Penelitian ini bertujuan untuk mengetahui distribusi, kepadatan kerang Modiolus modulaides terhadap lingkungannya. Pengambilan sampel menggunakan metode purposive sampling dengan interval waktu sehari sekali, di 7 stasiun mulai bulan Februari-Juni 2015. Total kerang coklat yang ditemukan sebanyak 1.453 individu. Data kepadatan dan distribusi kerang dianalisis secara deskriptif dengan menggunakan rumus yang telah baku. Hasil analisis distribusi kemudian dilakukan uji lanjutan dengan chi kuadrat $\left(\chi^{2}\right)$ sedangkan preferensi habitat kerang coklat (Modiolus modulaides) dianalisis dengan Principle Componen Analysis (PCA) dan Coresponden Analysis (CA) melalui program XLSTAT 2014. Kepadatan kerang coklat berkisar 6,33-32,20 ind $/ \mathrm{m}^{2}$. 
Hasil analisis kelas ukuran kerang terdistribusi dalam 12 kelas yaitu kerang ukuran kecil (muda), kerang ukuran sedang (dewasa) dan kerang ukuran besar (tua), yang masing-masing terdistribusi berturut-turut 0,2-4,65 cm, 4,7-7,6 $\mathrm{cm}$ dan 7,65-8,7 cm. Peningkatan jumlah kepadatan kerang berkorelasi terhadap tingkat kekasaran substrat dan kehadiran vegetasi lamun dan mengrove sementara pengelompokkan kerang berhubungan dengan tipe substrat, arus, serta interaksinya dengan organisme bentik lain. Preferensi habitat kerang Modiolus modulaides dikarakteristikkan oleh substrat pasir sangat kasar, butiran pasir halus, serta interaksinya dengan kondisi fisik, kimia dan biologi perairan (arus, khlorofil-a, TOM, oksigen terlarut, suhu, kecerahan) serta kehadiran vegetasi lamun dan mangrove.

Kata kunci: Kerang coklat, preferensi habitat, kepadatan, distribusi ukuran

\section{DOI: http://dx.doi.org/10.33772/jspi.v1n1.xxxx}

\section{PENDAHULUAN}

Kerang coklat (Modiolus modulaides) merupakan salah satu jenis kerang yang mendiami habitat di wilayah pesisir Teluk Kendari Sulawesi Tenggara. Kerang ini hidup melekat pada substrat keras menggunakan alat/organ byssusnya. Spesies ini mampu beradaptasi pada parameter lingkungan yang luas (Razek et al., 2014). Faktor lingkungan yang menjadi pembatas penyebaran spasial bivalvia meliputi pasang surut, suhu, gerakan arus, salinitas, oksigen terlarut, partikel tersuspensi (TSS), tipe substrat, ketersediaan makanan dan faktor biologi seperti kompetisi dan predasi (Akhrianti, 2014). Safriel et al., (1980); Oliver (1992) distribusi Modiolus auriculatus dan bivalvia lain ditentukan oleh sifat substrat. Setyobudiandi et al., (2004) keberadaan dan distribusi kerang Meretrix meretrix di pengaruhi oleh keadaan lingkungan dan tingkat eksploitasi.

Kerang Modiolus modulaides merupakan salah satu jenis kerang ekonomis. Napata et al., (2011) kerang coklat pada genus yang sama yaitu Modiolus metcalfei dan kerang hijau (Perna viridis) memiliki kandungan protein lebih tinggi masingmasing $71,49 \%$ berat basah dan $67,10 \%$ berat kering dibanding dengan kerang hijau (Perna viridis) yaitu $63,94 \%$.

Pemanfaatannya sampai saat ini masih terus dilakukan dan cenderung menitikberatkan pada kegiatan eksploitasi. Rajagopal et al., (2006) menunjukkan bahwa kerang Modiolus modiolus merupakan taksa target utama bagi nelayan skala kecil. Bivalvia seperti tiram, kerang remis termasuk dalam kelas moluska adalah kelompok yang menetap (sedentary) pada substrat dan tidak memiliki kemampuan yang baik dalam melawan predator, khususnya manusia yang menyebabkan populasi bivalvia lebih mudah dieksploitasi (Napata dan Andalecio, 2011). Pada sisi lain meningkatnya aktivitas pembangunan di darat dan di laut menimbulkan dampak terhadap kerusakan ekosistem termasuk tipe habitat dari biota tersebut. Mengingat belum adanya pembatasan waktu, jumlah dan ukuran kerang yang diperbolehkan untuk diambil menjadikan pemanfaatannya menjadi tidak terkendali. Berdasarkan hal tersebut upaya perlindungan serta pengelolaannya perlu dilakukan untuk menjamin keberlanjutannya. Dengan demikian penelitian mengenai preferensi habitat kerang $M$. modulaides sangat diperlukan untuk memperoleh informasi karakteristik habitatnya.

Penelitian ini bertujuan untuk mengetahui distribusi, kepadatan kerang Modiolus modulaides terhadap lingkungannya di perairan Teluk Kendari Sulawesi Tenggara.

Hasil penelitian ini diharapkan menjadi bahan informasi terkait habitat yang mendukung keberadaan kerang M. modulaides serta dijadikan pertimbangan dalam menentukan pengelolaan yang tepat bagi kerang $M$. modulaides sehingga keseimbangan populasinya berkelanjutan dan lestari.

\section{METODE PENELITIAN}

Penelitian ini dilakukan pada Perairan bagian dalam dan luar Teluk Kendari Sulawesi Tenggara (Gambar 1), di mulai bulan Februari sampai Juni 2015.

Pengambilan sampel mengunakan metode purposive dengan frekuensi pengambilan kerang sehari sekali untuk 7 stasiun. Setiap stasiun dilakukan pengambilan sebanyak 3 kali ulangan pada petakan berukuran $1 \times 1 \mathrm{~m}^{2}$. Selanjutnya semua sampel yang ditemukan dihitung jumlahnya, kemudian dilakukan pengukuran panjang cangkang memakai jangka sorong dengan ketelitian $0,01 \mathrm{~mm}$. Penentuan stasiun penelitian yang memberikan keterwakilan pada setiap kondisi ekologi didasarkan pada aktivitas kegiatan manusia, keberadaan ekosistem lamun dan mangrove. 


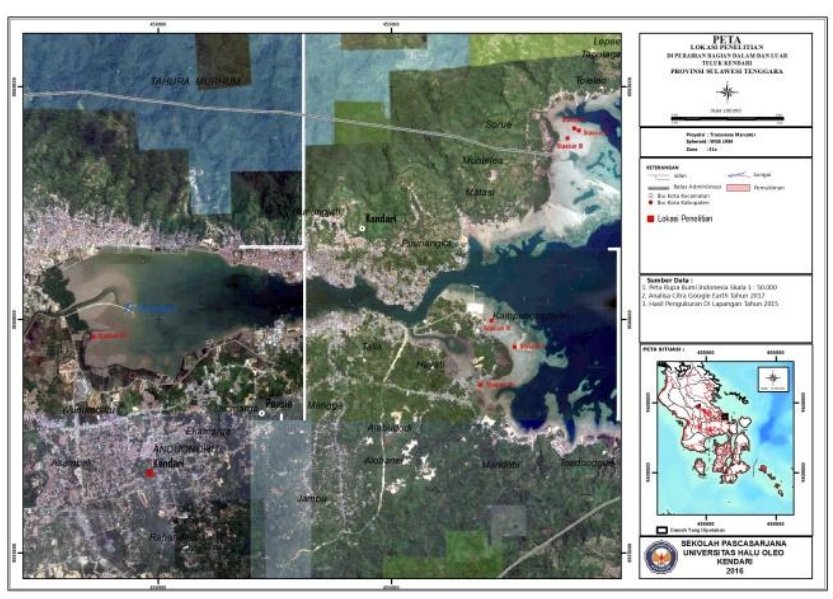

Gambar 1. Peta Lokasi Penelitian

\section{Analisis Data}

\section{Kepadatan Kerang M. modulaides}

Kepadatan kerang $M$. modulaides di setiap stasiun menggunakan rumus yang dikemukakan oleh Soegianto (1994).

$$
D=\frac{n i}{A}
$$

Keterangan :

$$
\begin{aligned}
& \mathrm{D}=\text { kepadatan kerang } M . \text { modulaides }\left(\mathrm{ind} / \mathrm{m}^{2}\right) \\
& \mathrm{ni}=\text { jumlah individu kerang } M . \text { modulaides (ekor) } \\
& \mathrm{A}=\text { luas daerah pengamatan }\left(\mathrm{m}^{2}\right)
\end{aligned}
$$

\section{Sebaran Distribusi Ukuran Cangkang}

Analisis distribusi ukuran panjang cangkang kerang M. modulaides adalah data ukuran panjang cangkang dikelompokkan ke dalam kelas-kelas panjang. Penentuan selang kelas ukuran panjang cangkang adalah $1+3.3 \log \mathrm{N}$, sedangkan panjang selang kelas $\left(\mathrm{P}_{\text {maksimum }}-\mathrm{P}_{\text {minimum }}\right)$ dibagi dengan jumlah selang kelas yang sudah diperoleh sebelumnya (Walpole, 1995).

\section{Sebaran Karakteristik Fisika, Kimia Perairan dan Substrat}

Karakteristik habitat di suatu area studi dihitung dengan menggunakan Principle Component Analysis (PCA) dengan rumus berikut:

$$
a^{2}(i, i)=\frac{\sum\left(X_{i j}-X_{i}{ }^{2}\right)^{2}}{X_{j}}
$$

Keterangan :

$\mathrm{X}_{\mathrm{i}}=$ jumlah baris $\mathrm{i}$ pada kolom $\mathrm{j}$
$\mathrm{X}_{\mathrm{j}} \quad$ = jumlah kolom $\mathrm{j}$ untuk semua baris $\mathrm{i}$

Analisis Komponen Utama (PCA) merupakan metode statistik deskriptif yang bertujuan untuk mempersentasikan bentuk grafik informasi maksimum yang terdapat dalam suatu matriks data. Matriks data terdiri atas stasiun pengamatan sebagai individu statistik (baris) dan karakteristik fisika-kimia air dan substrat sebagai variabel kuantitatif (kolom). (Legendre dan Legendre, 1983).

\section{Sebaran Spasial Kerang berdasarkan Kelas Ukuran}

Distribusi kerang Modiolus modulaides berdasarkan kelas ukuran dapat diketahui dengan menggunakan analisis Faktorial Koresponden (Correspondence Analysis, CA) (Bengen, 2000). Analisis CA umumnya digunakan untuk mengetahui karakteristik distribusi jenis biota.

$$
d^{2}(i, i)=\frac{\sum\left(X_{i j} / X_{i}-X_{i j} / X_{j}\right)^{2}}{X_{j}}
$$

Keterangan :

$\mathrm{X}_{\mathrm{i}}=$ jumlah baris $\mathrm{i}$ untuk semua kolom $\mathrm{j}$

$\mathrm{X}_{\mathrm{j}}=$ jumlah kolom $\mathrm{j}$ untuk baris ke-i.

Analisis Faktorial Korespon dan (Corespondence Analysis, CA) didasarkan pada matriks data yang terdiri atas i baris (kelas ukuran kerang) dan $\mathrm{j}$ kolom (stasiun pengamatan atau parameter fisika-kimia air dan substrat. Pengolahan data Analisis Komponen Utama (PCA) dan Analisis Faktorial Koresponden (CA) dilakukan dengan menggunakan program komputer Excel Stat 2014.

\section{HASIL DAN PEMBAHASAN}

\section{Hasil}

\section{Kepadatan Kerang Coklat}

Hasil penelitian yang ditemukan selama bulan Februari sampai Juni 2015 kerang Modiolus modulaides di Perairan dalam dan luar Teluk Kendari sebanyak 1.453 individu. Secara spasial kepadatan rata-rata individu kerang $M$. modulaides ditemukan tertinggi pada stasiun VII $\left(32,20 \mathrm{ind} / \mathrm{m}^{2}\right)$ dan terendah pada stasiun IV $\left(6,33 \mathrm{ind} / \mathrm{m}^{2}\right)$ (Gambar 2). 
La Ode Musni et al.

JURNAL SAINS dan INOVASI PERIKANAN / Journal of Fishery Science and Innovation

Vol. 1, No. 1, 31-39, Januari 2017

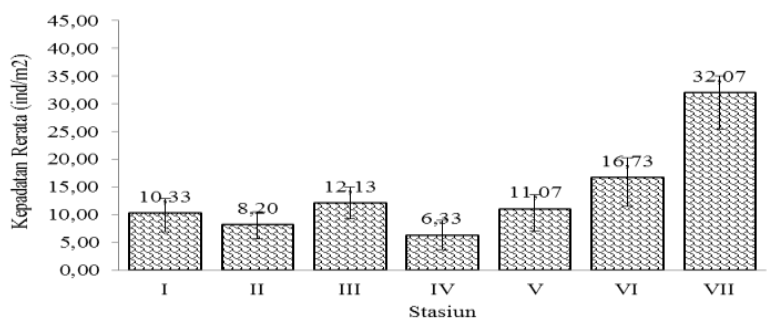

Gambar 2. Kepadatan rerata kerang M. modulaides pada stasiun penelitian

\section{Ukuran Kerang Hasil Tangkapan Total}

Hasil tangkapan total kerang selama penelitian terdistribusi dalam 12 selang kelas ukuran. Selang kelas ukuran dibagi 3 distribusi ukuran, yaitu kerang ukuran 0,2-4,65 cm kategori kecil (muda), kerang ukuran 4,7-7,6 cm kategori sedang (dewasa), dan kerang ukuran 7,65-8,7 cm kategori besar (tua) (Gambar 3).

Hasil pengukuran panjang cangkang selama penelitian ditemukan ukuran panjang minimum kerang yaitu $0,2 \mathrm{~cm}$ sedangkan ukuran panjang maksimum yaitu 8,7 cm (Gambar 4).
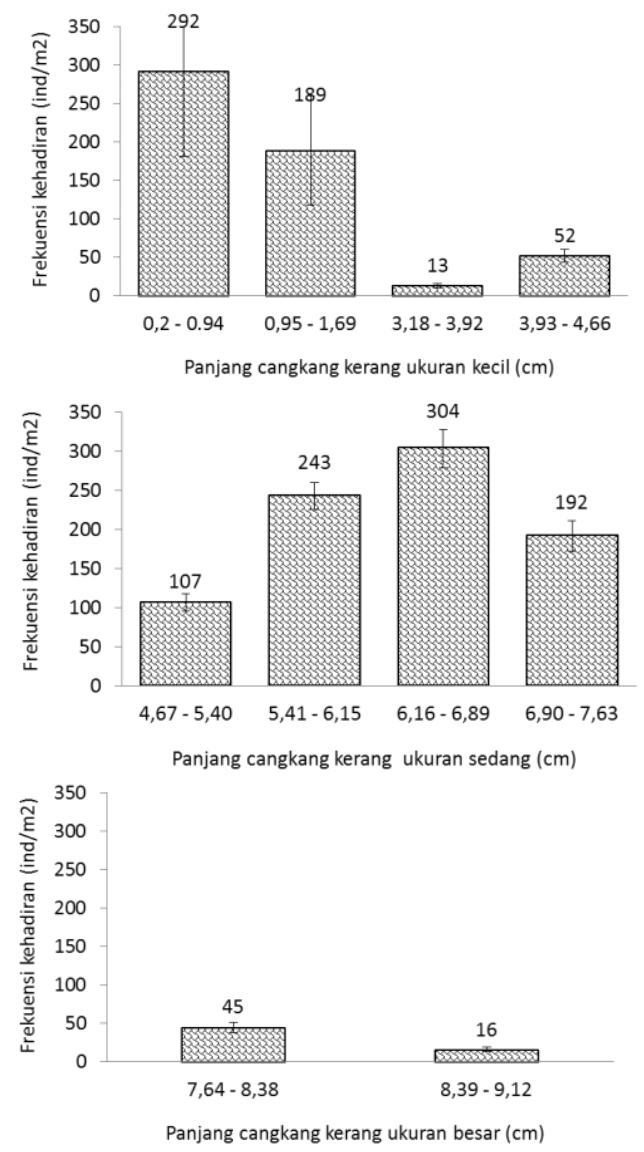

Gambar 3. Distribusi ukuran kerang M. Modulaides

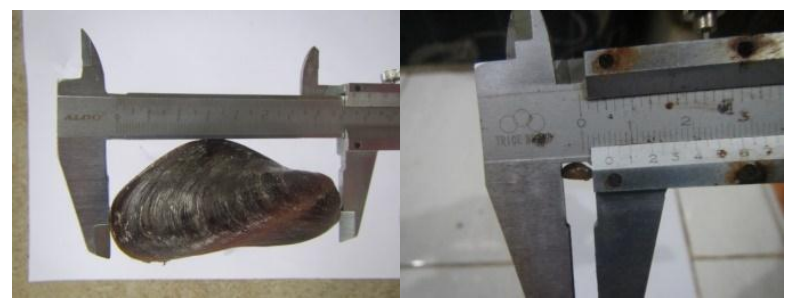

Gambar 4. Perbandingan ukuran kerang yang tertangkap

\section{Karakteristik Habitat Kerang Coklat}

Berdasarkan pengukuran parameter kualitas air dan substrat menunjukkan adanya kemiripan antar stasiun penelitian, sehingga dilakukan pengujian perbedaan/kemiripan habitat dengan menggunakan analisis pengelompokkan (percent similarity) melalui olahan data program XLSTAT 2014. Hasil analisis memberikan gambaran terbentuknya 3 kelompok stasiun. Kelompok A (stasiun VII), kelompok B (stasiun I, III, V, VI), dan kelompok C (stasiun II dan IV) (Gambar 5).

Stasiun VII letaknya dekat garis pantai, berada dekat dengan Sungai Wanggu serta merupakan daerah vegetasi mangrove dicirikan oleh persentase substrat lumpur dan bahan organik substrat yang tinggi. Stasiun II dan IV letaknya jauh dari pemukiman penduduk, merupakan daerah pencarian kerang, vegetasi lamun sedang (stasiun II), aktivitas pembangunan pelabuhan dan penimbunan, vegetasi lamun dan mangrove kurang (stasiun IV) dicirikan oleh kecepatan arus yang kuat dan tinggi oksigen terlarut, persentase substrat pasir sangat kasar yang tinggi dan rendah bahan organik substrat, khlorofil-a dan TOM. Kepadatan kerang yang tinggi dengan kondisi vegetasi mangrove dan lamun sedang sampai padat ditemukan pada stasiun I, III, V, VI dan VII yang dicirikan oleh komposisi substrat pasir sangat kasar, butiran substrat pasir halus, khlorofil-a, TOM relatif tinggi (I, III. V, VI) dan bahan organik substrat yang tinggi (stasiun VII). Stasiun III dan VI letaknya dekat dengan pemukiman penduduk dengan kondisi vegetasi lamun sedang sampai padat dan terdapat aliran sungai (stasiun VI), sedangkan stasiun I dan V letaknya jauh dari pemukiman penduduk, merupakan jalur transportasi dan tambatan perahu, terdapat usaha masyarakat produksi ayam potong dan kondisi vegetasi lamun sedang. 


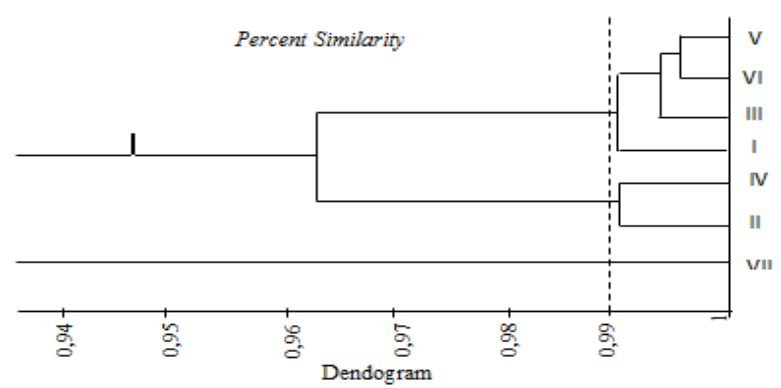

Gambar 5.Dendogram klasifikasi hierarki stasiun pengamatan berdasarkan kualitas air dan substrat

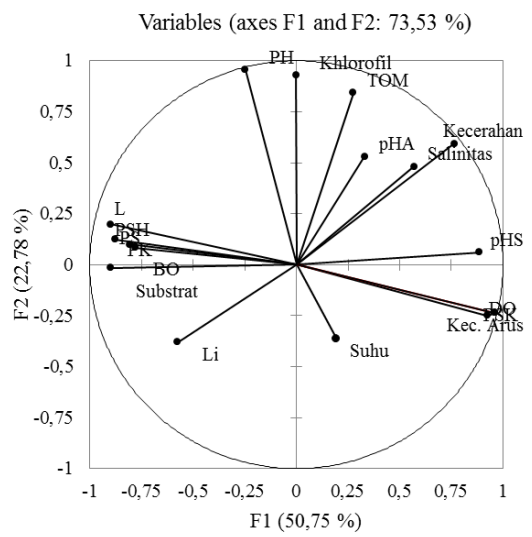

Gambar 6. Korelasi antar parameter habitat pada sumbu F1 dan F2

Analisis PCA memberikan informasi bahwa pada sumbu F1 (50,75\%) dicirikan oleh parameter DO, pH substrat, bahan organik substrat, kecepatan arus, tipe substrat pasir sangat kasar, dan lumpur. Sumbu F2 $(22,78 \%)$ dicirikan parameter khlorofil-a, TOM dan substrat pasir halus (Gambar 6), sedangkan Analisis Koresponden (CA) terhadap parameter lingkungan memberikan gambaran pemusatan informasi cukup dengan sumbu F1 dan F2 masing-masing sebesar $94.76 \%$ dan $4.30 \%$ dari ragam total sebesar $99.05 \%$. Grafik CA pada kedua sumbu F1 dan F2, parameter kualitas air dan tipe substrat berperan penting terhadap terbentuknya pengelompokkan di setiap stasiun (Gambar 7).

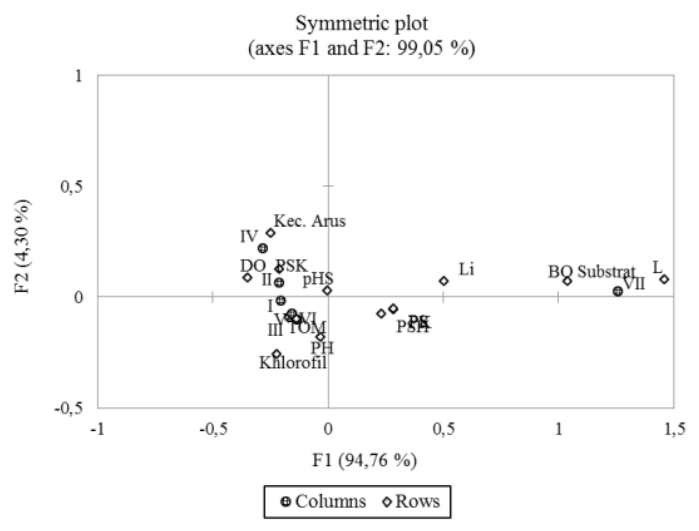

Gambar 7. Grafik Analisis Faktorial Koresponden (AFK) antara stasiun dengan parameter kualitas air dan substrat

\section{Preferensi Habitat Kerang Modiolus modulaides}

Analisis Faktorial Koresponden (AFK), memberikan informasi sebaran spasial yang terpusat pada sumbu $F 1$ dan $F 2$, masing-masing sumbu menjelaskan $47,73 \%$ dan $41,52 \%$ dari ragam totalnya. Kedua sumbu faktorial secara spasial membentuk 3 kelompok kelas ukuran.
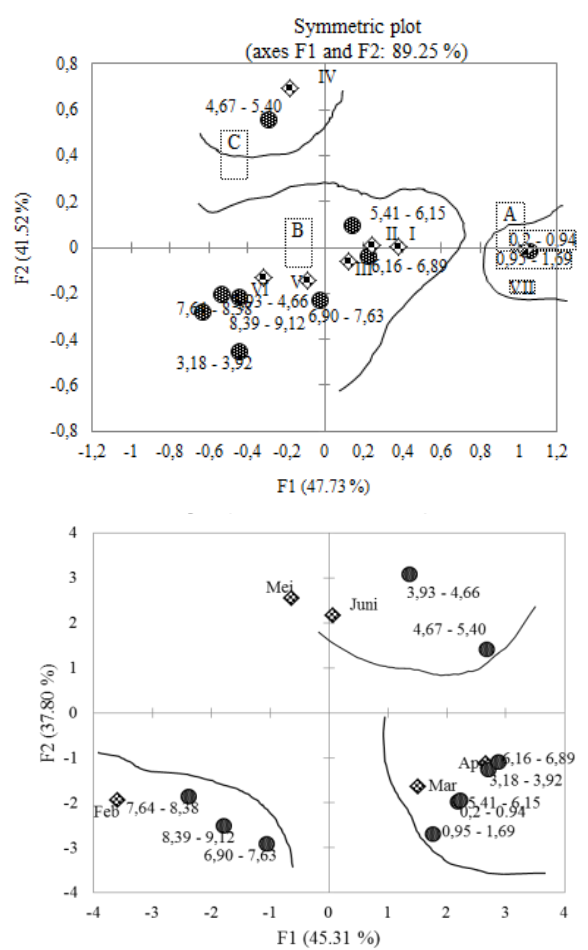

Gambar 8. Grafik Analisis Faktorial Koresponden (AFK) kelas ukuran kerang berdasarkan stasiun dan waktu penelitian pada sumbu F1 dan F2 
Pengelompokkan distribusi kerang coklat secara temporal pada bulan Maret dan April ditemukan terdistribusi pada ukuran kerang 0,2-0,94 cm, 0,95-1,1 cm, 3,18-3,92 cm, 5,41-6,15 cm, 6,16-6,89 cm. Pada bulan Februari frekuensi kehadiran kerang terdistribusi pada ukuran sedang (dewasa) sampai besar (tua) yaitu 6,90-7,63 $\mathrm{cm}, 7,64-8,38 \mathrm{~cm}$ dan $8,39-8,7 \mathrm{~cm}$ dan pada bulan Juni kerang coklat terdistribusi pada ukuran 3,93-4,66 $\mathrm{cm}$ dan 4,67-5,40 cm (Gambar 8).

Selanjutnya hasil pengelompokkan kelas ukuran panjang cangkang terhadap keberadaan kerang dalam menempati habitatnya menghasilkan peta preferensi dimana untuk kelas ukuran panjang cangkang 5,41$6,15 \mathrm{~cm}, 6,16-6,85 \mathrm{~cm}$ dan $\quad 6,90-7,63 \mathrm{~cm}$ mempunyai persentase penilaian tingkat kepuasan sebesar 75\% (Gambar 9).

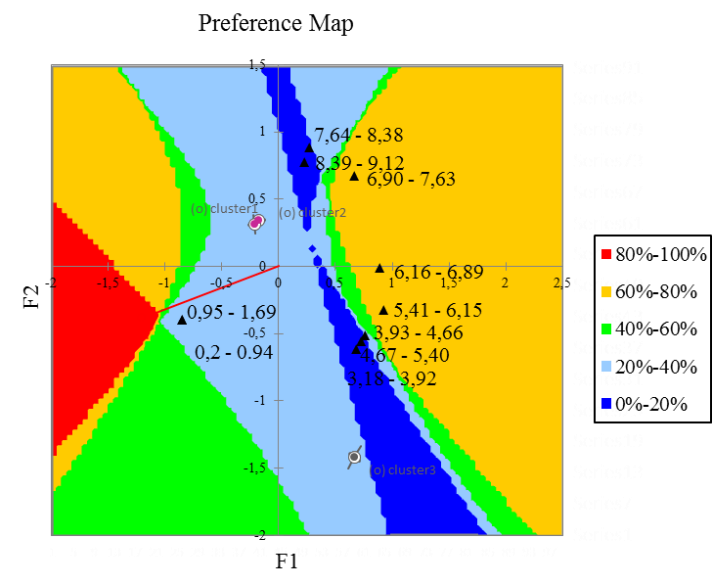

Gambar 9. Peta Preferensi kelas ukuran panjang cangkang kerang $M$. modulaides

\section{Pembahasan \\ Kepadatan Kerang}

Hasil penelitian ini menunjukkan bahwa tersedianya tipe substrat seperti pasir sangat kasar, butiran pasir halus serta akar mangrove dari jenis Avicennia sp. sangat mempengaruhi kehadiran jumlah kerang dari jenis $M$. modulaides (Gambar 2). Manoj et al., (2003) pada saat kerang muda mencapai stadia akhir dalam siklus hidupnya, kerang memerlukan permukaan yang padat seperti batu, kayu, tali dan kerang lainnya untuk melekat secara permanen dengan bantuan benang byssus. Benang byssus merupakan hal penting dalam menstabilkan sedimen dengan menjebak bahan-bahan kasar atau padat.
Berdasarkan analisis tekstur substrat memberi gambaran bahwa pada ekosistem mangrove persentase kerang berukuran kecil (muda) 0,2-1,1 cm sebanyak $33,10 \%$ (481 ind $/ \mathrm{m}^{2}$ ) sedang ukuran 3,2-4,65 cm dengan persentase $4,47 \% \quad\left(65 \mathrm{ind} / \mathrm{m}^{2}\right)$ ditemukan pada substrat pasir sangat kasar, substrat pasir halus dan vegetasi lamun. Persentase kerang ukuran sedang (dewasa) pada substrat butiran pasir halus, terdapat vegetasi lamun dan mangrove, ditemukan 58,22\% $\left(846 \mathrm{ind} / \mathrm{m}^{2}\right)$ dan hanya $4,20 \%\left(61 \mathrm{ind} / \mathrm{m}^{2}\right)$, kerang berkuran besar (tua) pada substrat pasir sangat kasar dengan kehadiran vegetasi lamun dan mangrove. Fatma et al., (2014) menemukan kepadatan Modiolus auriculatus yang tinggi pada substrat dasar yang terdiri dari butiran kecil bercampur pasir serta terdapat vegetasi padat dari lamun dan makro alga. Kehadiran kerang juga sangat terkait dengan ketersediaan sumber makanan (khlorofil-a, bahan organik terlarut (TOM), serta adanya aliran sungai sangat memungkinkan banyak mendapat masukan bahan organik. Bengen (2002) keberadaan mangrove dan lamun sangat penting dalam memberikan suplai bahan organik pada substrat dasar perairan yang dimanfaatkan organisme bentik untuk pertumbuhan dan kelangsungan hidupnya.

Pada sisi lain tingginya aktivitas di lahan atas seperti adanya kegiatan pembangunan dermaga dan penimbunan memberi dampak pada ekosistem pesisir. Parameter fisik seperti arus menjadi faktor pembatas terhadap kehadiran kerang coklat. Arus yang kuat mengakibatkan kerang berukuran kecil tidak mampu mentolerirnya, sehingga laju penempelan benang byssus pada substrat sangat rendah. Comely (1978), daerah yang terkena arus kuat menguras energi kerang dan mengakibatkan rendahnya laju pertumbuhan. Sementara rusaknya ekosistem mangrove dan lamun berpengaruh terhadap suplai makanan dan habitat dasar.

La Sara (2014) menjelsakna bahwa ekositem lamun mempunyai peran ekologi penting dalam melakukan fotosintesis, menyediakan sumber makanan dasar, nutrien dan habitat. Parameter lingkungan seperti arus yang bermanfaat dalam mendistribusikan sumber makanan justru menjadi faktor pembatas terhadap kehadiran kerang pada daerah ini. Rendahnya persentase penutupan lamun memberikan konsekuensi terhadap produktivitas primer. Nilai rata-rata khlorofil-a dan TOM pada stasiun ini tergolong rendah masing-masing $2,55 \mathrm{mg} / \mathrm{l}$ dan $18,57 \mathrm{mg} / \mathrm{l}$. Pada sisi lain, kehadiran organisme 
seperti bintang laut dan kepiting berpengaruh terhadap keberadaan kerang $M$. modulaides utamanya kerang berukuran kecil. Predator, terutama kepiting dan bintang laut, memainkan peran penting dalam struktur populasi kerang $M$. modulaides sehingga mempengaruhi kelangsungan hidup kerang mencapai pertumbuhan dari remaja sampai dewasa (Anwar et al., 1990). Predator merupakan hal penting dalam rantai makanan yang dapat menyebabkan kepunahan maupun penurunan kepadatan spesies.

\section{Distribusi Ukuran Kerang}

Distribusi spasial kerang coklat setiap ukurannya ditemukan dengan jumlah yang berbeda. Hasil penelitian di setiap stasiunnya menunjukkan adanya tren kenaikan yang besar pada ukuran kerang sedang (dewasa), sementara kerang ukuran kecil dan tua cenderung trennya sangat rendah. Kondisi ini ditunjukkan pada stasiun II dan IV. Stasiun II adalah daerah dengan vegetasi lamun dan mangrove sedang, persentase substrat pasir sangat kasar yang tinggi dibanding stasiun lainnya, daerah ini dijumpai organisme bentik seperti jenis Anadara, bintang laut, bintang ular, bulu babi, kepiting serta merupakan daerah oleh sebagian masyarakat melakukan pencarian kerang. Begitu halnya dengan stasiun IV, perubahan lingkungan akibat aktivitas pembangunan dan penimbunan, rusaknya ekosistem, serta arus yang kuat mengakibatkan penghambatan terhadap laju penempelan kerang dalam melampirkan benang byssus ke substrat.

Dengan demikian faktor penting yang secara langsung mempengaruhi distribusi kerang M. modulaides adalah adanya perubahan kondisi habitat seperti hilangnya substrat akibat adanya sedimentasi, serta kehadiran organisme bentik. Rusaknya habitat dasar serta perubahan lingkungan akibat aktivitas pembangunan dan penimbunan mengakibatkan hilangnya substrat yang digunakan kerang untuk melekatkan diri. Odum (1993) pola sebaran mengelompok individu dilakukan sebagai suatu strategi dalam merespon perubahan lingkungan serta perubahan habitat dan proses reproduksi. Komala (2012); Leimena et al., (2005) distribusi suatu populasi terjadi karena adanya seleksi habitat, predasi dan kompetisi memperebutkan ruang, makanan terhadap spesies lainnya serta faktor lingkungan baik secara fisik maupun kimia. Fatma et al., (2014) pada daerah intertidal dan subtidal yang banyak ditemukan alga, lamun, patahan karang dan beberapa organisme bentik lainnya, seperti teripang, bintang laut dan crustasea, persentasi kerang Modiolus auriculatus yang mati lebih banyak dibandingkan yang hidup. Safriel et al., (1980) dan Oliver (1992) melaporkan bahwa distribusi Modiolus auriculatus berkaitan erat dengan kehadiran bivalvia lain yang ditentukan oleh sifat substrat.

\section{Preferensi Habitat Kerang Modiolus modulaides}

Berdasarkan pengelompokkan parameter lingkungan yang terbentuk menunjukkan frekuensi kehadiran ukuran kerang $M$. modulaides selama penelitian ditentukan oleh tipe substrat, ketersediaan makanan seperti kholorifl-a, TOM, bahan organik substrat, oksigen terlaut, dan arus yang relatif sedang. Substrat dan kandungan bahan organik berhubungan dengan ketersediaan makanan yang menjadi kebutuhan organisme di perairan.

Kerang M. modulaides ukuran sedang (dewasa) baik secara spasial maupun temporal ditemukan dengan kecenderungan jumlah frekuensi sebaran tertinggi (Gambar 8). Nasrawati (2015) dalam penelitiannya pada Pulau Bungkutoko dan Sorue Jaya menemukan kerang jenis tersebut pada kelompok ukuran 6,54-6,88 cm kerang ukuran sedang (dewasa). Sementara hasil analisis peta preferensi memberikan infomasi bahwa kerang menunjukkan kesesuaiannya terhadap substrat keras, yang umumnya terdiri dari kerikil dan pasir sangat kasar, butiran pasir halus yang ditunjukkan dengan frekuensi kehadiran yang tinggi. Sementara keberadaan vegetasi mangrove dan lamun berperan dalam menyediakan sumber makanan dan tempat berlindung.

Kebanyakan jenis bivalvia menunjukkan preferensi terhadap substrat tertentu. Tiram lebih memilih substrat keras, atau substrat berpasir. Kerang dengan tingkah laku organsime penggali memiliki preferensi pada substrat lebih lembut dari pasir atau lumpur, atau campuran pasir/lumpur. Kerang jenis Mercenaria mercenaria, jumlah tertinggi ditemukan di pasir atau lumpur (Gosling, 2003). Holt et al., (1998) menyebutkan preferensi habitat/substrat dari kerang Modiolus modiolus terdiri dari pasir kasar, pasir halus, kerikil, batu besar hingga batu sangat besar, substrat campuran lumpur, kerikil berlumpur, pasir berlumpur, kolam-kolam batu, lumpur berpasir, habitat batu-batu kecil, habitat batu-batu yang terdapat dalam sedimen. Fatma et al., (2014) menemukan kerang Modiolus auriculatus dipengaruhi oleh jenis substrat. Kehadiran kerang $M$. auriculatus yang 
La Ode Musni et al.

JURNAL SAINS dan INOVASI PERIKANAN / Journal of Fishery Science and Innovation

Vol. 1, No. 1, 31-39, Januari 2017

ditemukan $51 \%$ individu di daerah substrat berbatu, $21 \%$ individu dengan karakteristik dasar perairan terdiri dari partikel-partikel kecil/halus bercampur pasir, dan juga pada daerah dengan kepadatan vegetasi yang tinggi ditumbuhi makroalga dan lamun, $16 \%$ di daerah batu berpasir, $7,5 \%$ di daerah batu berlumpur yang ditumbuhi alga dan $4 \%$ di daerah batu berpasir yang ditumbuhi alga). Selanjutnya Akhrianti (2014) menemukan karakteristik substrat berpasir, arus kuat, organik karbon rendah merupakan habitat yang ideal untuk kehidupan kerang filter feeder jenis Gafrarium tumidum dan Gafrarium pectinatum; sedangkan kerang jenis $S$. pilula dicirikan oleh karakteristik habitat lempung berdebu, substrat berpasir, arus lemah, C-organik tinggi merupakan preferensi habitat yang sesuai bagi kehidupannya. Thompson, (1996) menyatakan bahwa ketersediaan makanan Modiolus modiolus tergantung pada fluktuasi musim. Aktivitas makan berkurang di musim dingin dan meningkat di musim panas saat fitoplankton banyak tersedia, sehingga efisiensi penyerapan sangat tinggi di waktuwaktu musim panas. Pattikawa (2007) menyatakan preferensi habitat dari jenis Anadara berkaitan erat dengan pola distribusinya.

\section{KESIMPULAN}

Berdasarkan hasil penelitian dapat disimpulkan sebagai berikut :

1. Distribusi kerang Modiolus modulaides ditemukan mengelompok, dipengaruhi oleh tipe substrat, arus, dan kehadiran organisme seperti bintang laut, bulu babi, kepiting dengan nilai kisaran 1,02-1,34.

2. Kepadatan kerang $M$. modulaides di perairan Teluk Kendari 32,20 ind $/ \mathrm{m}^{2}$ erat kaitannya dengan tersedianya substrat berupa akar mangrove dan arus, sementara pada perairan Bungkutoko dan Sorue Jaya masing-masing $16,60 \mathrm{ind} / \mathrm{m}^{2}$ dan $12,13 \mathrm{ind} / \mathrm{m}^{2}$ berkaitan dengan substrat pasir sangat kasar, butiran pasir halus dan kehadiran vegetasi lamun.

3. Preferensi habitat kerang $M$. modulaides dikarakteristikkan oleh substrat pasir sangat kasar pada kerang ukuran besar (tua) sementara butiran substrat pasir halus pada kerang ukuran sedang (dewasa), kehadiran vegetasi lamun dan mangrove yang padat.

\section{Ucapan Terima kasih}

Pada kesempatan ini penulis mengucapkan terima kasih kepada La Sara, Yusnaini dan Wa Iba, yang banyak membantu dalam penyelesaian naskah ini.

\section{DAFTAR PUSTAKA}

Akhrianti I., Bengen. D.G., Setyobudiandi. I., 2014. Distribusi Spasial dan Preferensi Habitat Bivalvia di Pesisir Perairan Kecamatan Simpang Pesak. IPB. Jurnal Ilmu dan Teknologi Kelautan Tropis. 6(1) : 171-185.

Anwar, N.A., Richardson, C.A. \& Seed, R., 1990. Age Determination, Growth Rate, and Population Structure of The Horse Mussel Modiolus modiolus. Journal of the Marine Biological Association of the United Kingdom. 70 : 441-457.

Bahtiar, 2005. Kajian Populasi Batissa violacea celebensis von Martens, 1897 di Sungai Pohara Kendari Sulawesi Tenggara. Tesis. IPB.

Bengen, D.G., 2002. Pedoman Teknis Pengenalan dan Pengelolaan Ekosistem Mangrove. Pusat Kajian Sumberdaya Pesisir dan Laut. Bogor. $88 \mathrm{hlm}$.

Fatma, A., Razek, A., Abu-Zaid, M.M., Helal, A.M, Abdel-Gaid, S.E., Aziz, T.A., 2014. The Distribution of Eared Horse Mussel, Modiulus auriculatus (Krauss, 1848) Along The Red Sea Coast of Egypt. Egyptian Journal of Aquatic Research. 40: 469-472.

Gosling, E., 2003. Bivalve Molluscs. Biology, Ecology and Culture. Fishing News Books division of Blackwell Publishing. 443 hal

Komala, R., 2012. Analisis Ekobiologi Sebagai Dasar Pengelolaan Sumberdaya Kerang Darah (Anadara granosa) di Teluk Lada Perairan Selat Sunda. Disertasi. Bogor.

Leimena, H.E.P., Tati, S.S. Subadar., dan Adianto. 2005. Estimasi Daya Dukung dan Pola Pertumbuhan Populasi Kerang Lola (Trocus niloticus) di Pulau Saparua Maluku Tengah. Jurnal Matematika dan Sains. 10(3) : 75- 80.

La Sara, 2014. Pengelolaan Wilayah Pesisir. Gagasan Memelihara Aset Wilayah Pesisir dan Solusi Pembangunan Bangsa. Alfabeta. Bandung.

Manoj, N.R. and Appukuttan, K.K., 2003. Effect of Temperature on The Development, Growth, Survival and Settlement of Green Mussel Perna viridis (Linnaeus, 1758). Aquaculture Research. 34 : 1037-1045.

Napata. R.P., Andalecio. M.A., 2011. Exploitation and Management of Brown Mussel (Modiolus 
philippinarum). Philippine Journal of Social Sciences and Humanities. University of the Philippines Visayas. 16(2): 22-34.

Nasrawati, 2015. Pertumbuhan, Kematian dan Tingkat Eksploitasi Kerang Coklat (Modiolus modulaides) di Perairan Teluk Kendari Sulawesi Tenggara. Journal of Fishery Science and Innovation. 1(1) : 1-8.

Odum, E. P., 1993. Dasar-Dasar Ekologi. Diterjemahkan oleh T. Samingan. Gadjah Mada University Press. Yogyakarta.

Oliver, P.G., 1992. Bivalved Seashells of The Red Sea Christa Hemmen Wiesbaden and National Museum of Wales, Cardiff, $\quad 330$ p.

Patikkawa. J.A., 2007. Pertumbuhan Kerang Bulu (Anadara antiquate) di Perairan Pantai Passo Teluk Ambon Maluku. Universitas PattimuraAmbon. 12(4) : 181-186.
Rajagopal, S., Venugopalan, V.P., Van Der Velde, G., \& Jenner, H.A. 2006. Mussel Colonization of a High Flow Artificial Benthic Habitat: Byssogenesis Holds The Key. Marine Environmental Research. $62,98-115$.

Riniatsih, I. dan Widianingsih, 2007. Kelimpahan dan Pola Sebaran Kerang-Kerangan (Bivalvia) di Ekosistem Padang Lamun, Perairan Jepara. Jurnal Ilmu Kelautan UNDIP. 12 (1) : 53-58.

Safriel, U.A., Gilboa, A., Felsenburg, T., 1980. Distribution of Rocky Intertidal Mussels in The Red Sea Coasts of Sinai, The Suez Canal and The Mediterranean Coast of Israel, With Special References to Recent Colonizers. $J$. Biogeogr. 7 : 39-62.

Setyobudiandi, I., E. Soekendarsih, Y. Vitner, dan R. Setiawati, 2004. Bioekologi Kerang Lamis (Meretrix meretrix) di Perairan Marunda. Jurnal Ilmu-Ilmu Perairan dan Perikanan Indonesia. 1 : 61-66. 